\title{
EVALUATING WATER EROSION RISKS IN SOME WADIS OF NORTHWESTERN COAST ZONE - EGYPT
}

\author{
EL-Kassas, H. I. ${ }^{(1)}$; Abd El-fattah. A. ${ }^{(2)}$;Hashem, Seham, A ${ }^{(1)}$ \\ and El-Sherbiny, G. M. ${ }^{(2)}$ \\ 1) Environmental Studies and Research, Ain Shams University 2) Desert \\ Research Center
}

\begin{abstract}
Field experiments were conducted in 2015 - 2016 winter season, at wadi El- Raml area. Wadi El - Raml is located southwest, Mersa Matruh city, Egypt. Slope of the experimental site is about 5 percent in south - north direction. The treatments were as follows: Bare soil, traditional cultivation without soil conditioners, cultivation with Ceramic conditioner at rate of 20, 40, and 80 t.fed-1, cultivation with bokashi conditioner at rate of 20,40, and 80 t.fed- 1 and coal ash conditioner at rate of 20, 40, and 80 t.fed-1. The total number of treatments was 11 . Each treatment was replicated 3 times. The soil conditioners was added on the soil surface after carrying out tillage operation and then mixed with the soil surface layer. Thirty-three bounded plots having edges of soil with approximately $20 \mathrm{~cm}$ height were used to determine soil loss associated with runoff. Each plot was $21 \mathrm{~m}$ length and $2 \mathrm{~m}$ width. At the down slope end, Gerlash trough were placed, $0.5 \mathrm{~m}$ long and $0.2 \mathrm{~m}$ wide, closed at the sides and covered with movable lid. An outlet pipe extended from the base of the gutter to the collection containers present below the soil surface. Rainfall amounts, duration, and intensity were measured for every rainstorm with an automatic rain gauge at the site of experiment. The amount of soil loss and runoff water for every rainstorm was determined by maintaining the containers undisturbed for a sufficient time, so that, the solid constituents in the runoff water could precipitate. The precipitated solids were collected and measured gravimetrically after drying at $105^{\circ} \mathrm{C}$ overnight.

Soils of wadi El Raml are mainly sandy loam in texture with deep soil profile. The climatic conditions of the area is defined as arid Mediterranean type, it is characterized by short rainy seasons during October to March. About 75 percent of the total annual rainfall as recorded from November to February. The remaining period of the year is characterized by long dry


season (6-7months), except for few rainy storms in April, May and September. The average annual rainfall is $175.4 \mathrm{~mm}$. the effective storms were sex storms the runoff coefficient of $3 \%$ seams reassemble. However, the lowest runoff yield was obtained when adding Bokashi conditioner with rate of 80 t.fed-1 under all storms,). It is clear that runoff values associated with bare soil were higher than those for the soil treated by non-traditional soil conditioners. From another point, Ceramic conditioner added on the soil surface with the rate of 20,40 and 80 t.fed- 1 led to reduce runoff by 37,49 and $56.5 \%$, respectively, as compared with cultivated soil . With respect to adding bokashi as soil conditioner on the soil surface with the rate 20,40 and 80 t.fed-1, runoff values under all storms was reduced to 45.2, 59.6 and $67.7 \%$, respectively, The influence of the applied traditional cultivation and applied some soil conditioners on the amount of soil loss under natural rainfall. The highest rates of soil losses resulted from bare soil treatment 1.23 ton/fed. Year this rate lies within the permissible limits of soil loss by erosion, which range from 1 to 5 tams per acre per yeas, With respect to planting without soil conditioners, it is clear that such practice reduced the amount of soil loss by $24.2 \%$ relative to that for bare soil treatment, This behavior could be attributed to the fact that plants protect a portion of the soil surface from the energy of rainfall impact, thereby, soil detachment decreased. Growing plants also create obstructions to eater flow over land, slowing down runoff velocity and consequently its carrying capacity and thus, reducing soil loss.

Key words: Water Erosion - Erosion Risks - Runoff - Soil Loss - Rainfall

\section{INTRODUCTION}

The semi-arid areas surrounding the Mediterranean Sea is seriously affected by soil degradation and desertification. Water erosion is the main degradation process, while human pressure, the reduction of plant cover and the nature of the parent material are the main causes of soil erosion, United Nation (1992). Bay Ram et al. (2003) and Rousseva et al. (2010) stated that soil erosion is one of the biggest global environmental problems resulting in both on-site and off-site effects. Soil erosion leads to decrease of rooting 
depth, amount of nutrients and available soil water; decline in organic matter; loss of biodiversity; and degradation of soil structure and soil crusting. Soil erosion has accelerated ino most parts of worlds especially in developing courtries.

Water erosion occurs on bare, sloping land when intense rainfall rates exceed a soil's infiltration capacity and runoff begins. The water concentrates into tiny streamlets, which detach the saturated soil and transport the particles downhill. Runoff water gains more energy as it moves down the slope, scouring away more soil and also carrying more agricultural chemicals and nutrients, which end up in streams, lakes, and estuaries Reduced soil health in many of our agricultural and urban watersheds has resulted in increased runoff during intense rainfall and increased problems with flooding. In addition, the lower infiltration capacity of degraded soils reduces the amount of water that is available to plants, as well as the amount that percolates through the soil into underground aquifers. This reduction in underground water recharge results in streams drying up during drought periods. Watersheds with degraded soils thus experience lower stream flow during dry seasons and increased flooding during times of high rainfall. Vegetation types widely differ in their efficiency to counteract soil erosion. Characteristics of vegetation affecting soil erosion include canopy characteristics such as leaf size, leaf area, leaf orientation, canopy cover, root characteristics such as soil binding capacity and plant density. Some cropping system effectively reduces erosion, but some others may enhance it. For example, erosion on plots 22.6 $\mathrm{m}$ long with an $8 \%$ slope had about 1,000 times more erosion when in continuous corn as compared with continuous bluegrass (Foth 1990). 
Soil erosion by water accounts for $75 \%$ of strongly degraded soils in the world (Jie et al., 2002) Both wind and water erosion are the dominant types of soil degradation worldwide accounting for over $50 \%$ of the world's land (Bot et al., 2000, Jie et al., 2002. Soil conditioner is a product that is added to soil led to improve the soil quality. Soil conditioners can be used to rebuild soils, which have been damaged by improper management, to make poor soils more usable, and to maintain soils in peak condition. Major problems encountered in the present day agriculture are low soil fertility and inadequate water retention. Wind erosion, water erosion, drought and loss of irrigation water and plant nutrients are also other probable reasons. Adding soil polymers to the soil surface can serve as an option to prevent soil erosion. Small amounts of negative polymers (<20 kg/ha) with very high molecular weight (10 million $\mathrm{g} / \mathrm{mol}-20 \mathrm{million} \mathrm{g} / \mathrm{mol}$ ), added to the soil surface, either in solution or dry, are effective in preventing particles detachment and hydraulic shear stress. The use of polymers to prevent furrow erosion is already practiced on $>1$ million ha. Applying dissolved PAM to the soil surface was effective in preventing runoff and erosion. However, this practice is difficult to apply under rain-fed conditions. The efficiency of spreading dry PAM, mixed with gypsum or soil material, in preventing erosion under rain-fed conditions is in its early stages of research. Further research is needed to fully understand and establish whether their use for agricultural and environmental purposes is economically feasible. 


\section{MATERIALS AND METHODS}

Field experiments were carried out at Wadi El-Raml, which located in Northwestern Coast Zone, Matrouh, Egypt. The slope of soil surface is 5\% in south- north direction, which determined by Abney Level instrument through taking the soil surface elevation every $5 \mathrm{~m}$ from the middle of each site. Surface soil samples $(0-30 \mathrm{~cm})$ were randomly taken. Particle size distribution using the pipette method, Soil reaction $(\mathrm{PH})$, electrical conductivity (EC), organic matter (OM), cation exchange capacity (CEC), calcium carbonates $\left(\mathrm{CaCO}_{3}\right)$, total nitrogen (TN), available phosphors (AV.P) and exchangeable potassium (Ex.K) were determined according to Page et al. (1982) and Klute (1986). Soil bulk density and soil moisture were measured by a core sample according to Klute (1986) method. Location map of the study area was shown in Fig. (1). The amount of rainfall during the winter season 2015/2016, at the experimental site at wadi El-Raml, NWCZ of Egypt was measured with an automatic rain gauge (digital instrument). Rainfall amounts, duration, and intensity were measured for every rainstorm with an automatic rain gauge at the site of experiment. The field experiments were conducted during winter season 2015 / 2016. Chisel plow was used to operate soil tillage before adding non-traditional soil conditioners. The experimental area was about $1500 \mathrm{~m}^{2}$ approximately. The experimental field was divided into plots $(2 \times 21 \mathrm{~m})$ with slope of $5 \%$, according to Hudson (1993). 
J. Environ. Sci.

Institute of Environmental Studies and Research - Ain Shams University

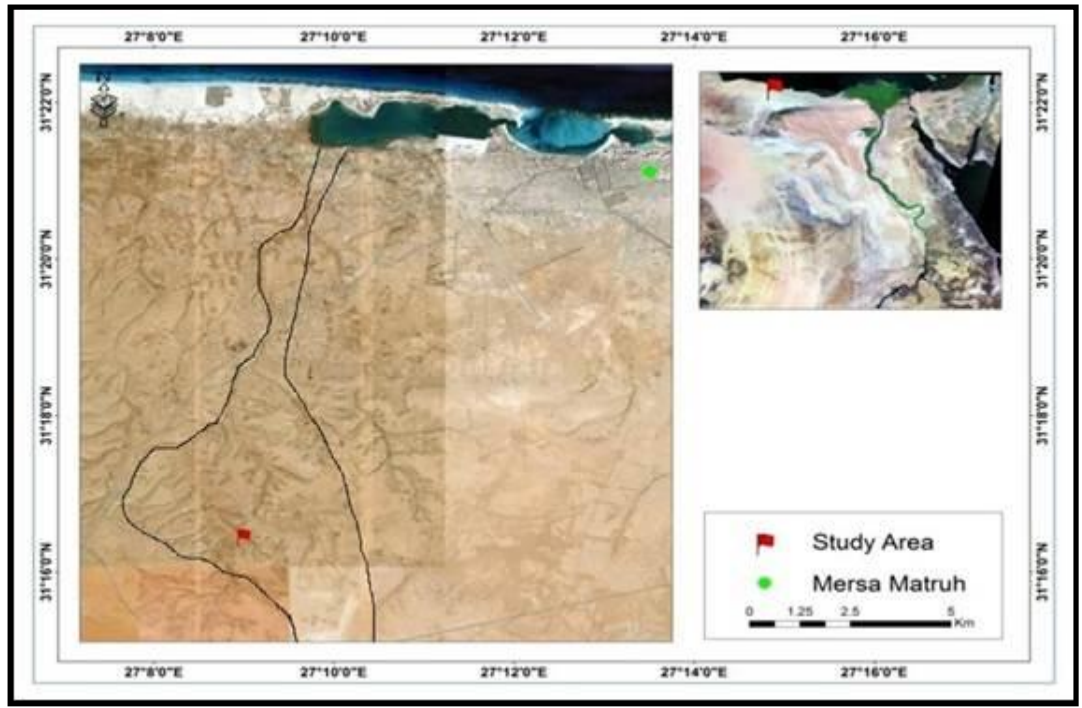

Fig. (1): Location map of the experimental site at Wadi El-Raml, NWCZ of Egypt.

The total number of treatments was 11 . Each treatment was replicated 3 times. Thirty-three equal plots $\left(42 \mathrm{~m}^{2}\right)$ having edges of soil with approximately $20 \mathrm{~cm}$ height were used to determine soil loss associated with runoff. The distance between treatments was kept at $2 \mathrm{~m}$, which created a buffer zone area. Each treatment was surrounded by the earth hurdles height of $20 \mathrm{~cm}$. Non-traditional soil conditioners; i.e. Ceramic, Bokashi and Coal ash conditioners with rate of 20,40 , and $80 \mathrm{t}_{\mathrm{fed}}{ }^{-1}$, was added on the soil surface after carry out tillage operation and then mixed with the soil surface layer. The treatments were as follows: Bare soil, traditional cultivation without soil conditioners, cultivation with Ceramic conditioner at rate of 20 , 40, and 80t.fed ${ }^{-1}$, cultivation with Bokashi conditioner at rate of 20, 40, and $80 t . \mathrm{fed}^{-1}$ and Coal ash conditioner at rate of 20,40, and 80t.fed ${ }^{-1}$. Figur (6,) 
illustrate the experimental field design and treatments used for rainwater harvesting at wadi El-Raml, NWCZ of Egypt. At the down slope end, Gerlash trough, Morgan (2005), were placed, $0.5 \mathrm{~m}$ long and $0.2 \mathrm{~m}$ wide, closed at the sides and covered with movable lid to collect the surface runoff and suspended eroded materials after each effective rainfall event, as shown in Fig. (12). An outlet pipe extended from the base of the gutter to the collection containers present below the soil surface. The amount of soil loss and runoff water for every rainstorm were determined by maintaining the containers undisturbed for a sufficient time, so that, the solid constituents in the runoff water could precipitate. The precipitated solids were collected and measured gravimetrically after drying at the $105^{\circ} \mathrm{C}$ overnight.

\section{RESULTS AND DISCUSSION}

The results of the soil analysis for some physical and chemical properties of the experimental site at Wadi-El-Raml are given in Tables (1A, 1b). It is clear that the soil of Wadi El-Raml is sandy loam in texture and calcareous, where $\mathrm{CaCO}_{3}$ content vary between 9.72 to $11.78 \%$ for different soil layers. The average bulk density is $1.4 \mathrm{~g} . \mathrm{cm}^{-3}$, approximately, for all soil layers. In addition, the data indicate that the soil is non-saline, where its electrical conductivity ranged between 0.85 and $1.14 \mathrm{ds} . \mathrm{m}^{-1}$ for different soil layers. The dominant cations, are sodium followed by calcium, while the dominant anions are chloride followed by sulphate. The CEC values vary from 13.0 to $15.1 \mathrm{meq} .100 \mathrm{~g}^{-1}\left(\mathrm{cmol}^{\mathrm{kg}}{ }^{-1}\right)$ for different soil layers. The soil is poor in organic matter, where its values varied from 0.15 to $0.22 \%$ for different soil layers. The values of total nitrogen, available phosphorous and exchangeable 
potassium are very low, where it their values varied from 0.02 to $0.05,0.7$ to 0.81 and from 0.4 to 0.55 , respectively. From the abovementioned data, it can beconcluded that the soil of the experimental site at Wadi El-Raml is shallow, sandy clay loam in texture, calcareous, non-saline, poor in organic matter and low in fertility. Therefore, conserving these soils from water erosion hazards is very important challenge to combat the desertification, especially under North Western Coast Zone environment.

\section{Precipitation Events Characterizes:}

The depth and daily rainfall distribution during the study periods for the experimental site are given in Table (2). The rainy day is defined when the rainfall was $<1 \mathrm{~mm}$, Climatological Normals for the Arab Republic of Egypt (1979), thus, the total annual rainfall during the study period for winter season of 2015 - 2016 was $186.1 \mathrm{~mm}$. Eleven storms occurred in the winter season of 2015 - 2016. Six storms were effective as they caused runoff and consequently soil loss, where the depth of rain was greater than $10 \mathrm{~mm}$. The total depth of rainfall for the six storms was $87.3 \%$, and represented about $47 \%$ of the total rain that fall on the winter season 2015 / 2016. Rainfall intensities for the effective storms varied between 3.7 to $9.7 \mathrm{~mm} / \mathrm{hr}$. Therefore, it is anticipated that there was relation between the depth of rainfall and water erosion. Hence, as the amount of rainfall increased runoff increased and vice versa. On the contrary, there was no relation between the number of rainy days and water erosion under the prevailing conditions during the present study. It is clear that runoff occurred when the depth of rainfall of the individual storm at any intensity exceeded $10 \mathrm{~mm}$. Similar 
results are confirmed with that reported by Hudson (1981). It is also evident that rainfall intensity gave no indication to the amount of runoff caused by the effective storm. From abovementioned data, there are relationship between rainfall intensity for the effective storms and both runoff and soils loss. To delineate such relationships under the various conditions, the discussion will be presented as follows:

Table (1): Some physical and chemical properties of the studied soil at Wadi El- Raml area, NWCZ of Egypt.

\begin{tabular}{|c|c|c|c|c|c|c|c|}
\hline \multirow{2}{*}{$\begin{array}{l}\text { Soil } \\
\text { depth } \\
(\mathrm{cm})\end{array}$} & \multirow{2}{*}{$\begin{array}{c}\text { Bulk } \\
\text { density } \\
\left(\mathrm{gm} \cdot \mathrm{cm}^{-3}\right)\end{array}$} & \multirow{2}{*}{$\begin{array}{c}\mathrm{CaCO} 3 \\
(\%)\end{array}$} & \multicolumn{4}{|c|}{ Particle size distribution (\%) } & \multirow{2}{*}{$\begin{array}{c}\text { Texture } \\
\text { class }\end{array}$} \\
\hline & & & Clay & Silt & $\begin{array}{l}\text { Fine } \\
\text { Sand }\end{array}$ & $\begin{array}{c}\text { Coarse } \\
\text { Sand }\end{array}$ & \\
\hline $0-20$ & 1.32 & 9.95 & 16.85 & 11.80 & 67.90 & 3.45 & $\begin{array}{c}\text { Sandy } \\
\text { loam }\end{array}$ \\
\hline $20-40$ & 1.37 & 10.53 & 17.01 & 11.23 & 67.15 & 4.61 & $\begin{array}{c}\text { Sandy } \\
\text { loam }\end{array}$ \\
\hline $40-60$ & 1.49 & 11.47 & 17.85 & 12.05 & 65.10 & 5.00 & $\begin{array}{c}\text { Sandy } \\
\text { loam }\end{array}$ \\
\hline \multicolumn{8}{|c|}{ (B): Chemical properties. } \\
\hline \multirow{2}{*}{$\begin{array}{l}\text { Soil } \\
\text { depth } \\
(\mathrm{cm})\end{array}$} & \multirow[b]{2}{*}{$\mathrm{PH}$} & \multirow[b]{2}{*}{$\begin{array}{c}\mathrm{EC} \\
\left(\mathrm{dS} \cdot \mathrm{m}^{-1}\right)\end{array}$} & \multirow[b]{2}{*}{$\begin{array}{l}\text { OM } \\
(\%)\end{array}$} & \multirow{2}{*}{$\begin{array}{c}\mathrm{CEC} \\
(\mathrm{Cmol} . \\
\left.\mathrm{kg}^{-1}\right)\end{array}$} & \multicolumn{3}{|c|}{ Nutrient content } \\
\hline & & & & & $\begin{array}{l}\text { T.N } \\
(\%)\end{array}$ & $\begin{array}{l}\text { Av.P } \\
\text { (ppm) }\end{array}$ & $\begin{array}{c}\text { Av. K } \\
(\text { com.kg) }\end{array}$ \\
\hline $0-20$ & 7.85 & 1.14 & 0.22 & 15.10 & 0.05 & 0.70 & 0.55 \\
\hline $20-40$ & 7.42 & 0.85 & 0.20 & 14.80 & 0.03 & 0.81 & 0.40 \\
\hline $40-60$ & 7.66 & 1.12 & 0.15 & 13.70 & 0.02 & 0.79 & 0.48 \\
\hline
\end{tabular}


J. Environ. Sci.

Institute of Environmental Studies and Research - Ain Shams University

Table (2): Daily distribution of rainfall during the winter seaso (2015/2016).

\begin{tabular}{|c|c|c|c|c|c|}
\hline \multirow{2}{*}{ Data storm } & \multicolumn{2}{|c|}{ Rainfall season (2015-2016 } & \multicolumn{2}{c|}{ Rainfall (mm) } \\
\cline { 2 - 6 } & $\begin{array}{c}\text { Depth } \\
(\mathbf{m m})\end{array}$ & $\begin{array}{c}\text { Duration } \\
(\mathbf{h r})\end{array}$ & $\begin{array}{c}\text { Rainfall } \\
\text { intensity } \\
(\mathbf{m m} / \mathbf{h r})\end{array}$ & $\begin{array}{c}\text { Bare } \\
\text { soil }\end{array}$ & $\begin{array}{c}\text { Traditional } \\
\text { cultivation }\end{array}$ \\
\hline \hline $5-11-2015$ & 2.4 & 11.2 & 0.2 & - & - \\
\hline $18-11-2015$ & 22.4 & 6 & 3.7 & 0.84 & 0.76 \\
\hline $21-11-2015$ & 3.1 & 10 & 0.3 & - & - \\
\hline $2-12-2015$ & 1.8 & 14 & 0.1 & - & - \\
\hline $9-12-2015$ & 26.8 & 6.3 & 4.3 & 0.94 & 0.86 \\
\hline $31-12-2015$ & 28.4 & 4.7 & 6 & 1.2 & 0.94 \\
\hline $5-1-2016$ & 36.9 & 3.8 & 9.7 & 1.6 & 1.22 \\
\hline $17-1-2016$ & 20.2 & 5 & 4 & 0.92 & 0.72 \\
\hline $23-1-2016$ & 27.5 & 3.7 & 7.4 & 1.4 & 0.92 \\
\hline $16-1-2016$ & 8.7 & 6 & 1.4 & - & - \\
\hline $18-3-2016$ & 7.9 & 8.2 & 0.9 & - & - \\
\hline total & 186.1 & & & 6.9 & 5.42 \\
\hline
\end{tabular}

Runoff Yield: Table (3) shows the influence of some non-traditional soil conditioners on the surface water runoff. Data reveal that the total depth of surface runoff or runoff yield from the bare soil treatment, i.e. control treatment, reached $6.90 \mathrm{~mm}$ during winter season $2015 / 2016$. This indicates that the average runoff coefficient approaches $3.75 \%$, i.e. how much of the rainfall run over the soil surface. Data in Table (3) illustrate that under all treatments increase of effective rainfall led to increase the rate of runoff. Data in Table (3) indicate that runoff was reduced to $22.3 \%$ with traditional cultivation without conditioners as compared to bare soil .These findings are in agreement with Viertman (1989), who mentioned that under the conditions of North Western Coast region of Egypt, the runoff coefficient of 3\% seems 
reassemble. However, the lowest runoff yield was obtained when adding

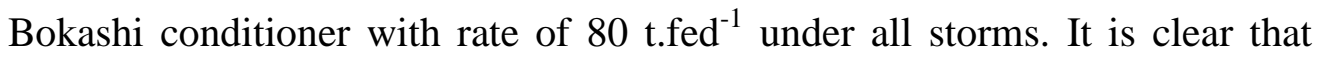
runoff values associated with bare soil was higher than that for the soil treated by non-traditional soil conditioners. From another point, ceramic conditioner added on the soil surface with the rate of 20, 40 and $80 \mathrm{t}_{\text {fed }}{ }^{-1}$ led to reduce runoff by 37,49 and 56\%, respectively, as compared with cultivated soil . With respect to adding bokashi as soil conditioner on the soil surface with the

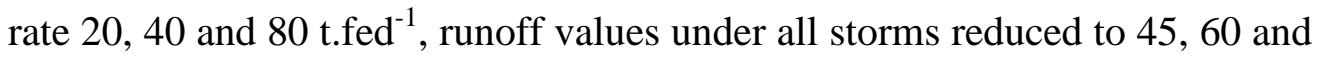
$67.7 \%$, respectively, as compared with cultivated soil. Similar results were showed by Morgan (2005) and Playford et al. (1993); they reported that canopy and adding coal ash as soil conditioners reduced runoff.

Table (3): Effect of non- traditional soil conditioners on surface water runoff (mm) during winter season 2015/2016 at Wadi El-Raml area.

\begin{tabular}{|c|c|c|c|c|c|c|c|c|c|c|c|c|}
\hline \multirow{2}{*}{ Date storm } & \multirow{2}{*}{$\begin{array}{l}\text { Rainfall } \\
(\mathrm{mm})\end{array}$} & \multirow{2}{*}{$\begin{array}{r}\text { Bare } \\
\text { soil }\end{array}$} & \multirow{2}{*}{$\begin{array}{c}\text { Traditional } \\
\text { Cultivation } \\
\text { without } \\
\text { conditioners }\end{array}$} & \multicolumn{3}{|c|}{$\begin{array}{c}\text { Cultivation with } \\
\text { Ceramic conditioner }\end{array}$} & \multicolumn{3}{|c|}{$\begin{array}{l}\text { Cultivation with Bokashi } \\
\text { conditioner }\end{array}$} & \multicolumn{3}{|c|}{$\begin{array}{l}\text { Cultivation with Coal } \\
\text { ashconditioner }\end{array}$} \\
\hline & & & & $\begin{array}{c}20 \\
\left(\text { t.fed }^{-1}\right)\end{array}$ & $\begin{array}{c}40 \\
\left(\text { (t.fed }^{-1}\right)\end{array}$ & $\begin{array}{c}80 \\
\left(\text { t.fed }^{-1}\right)\end{array}$ & $\mid \begin{array}{c}20 \\
\left(\text { t.fed }^{-1}\right)\end{array}$ & $\begin{array}{c}40 \\
\left(\text { t.fed }^{-1}\right)\end{array}$ & $\left|\begin{array}{c}80 \\
\left(\text { t.fed }^{-1}\right)\end{array}\right|$ & $\left(\begin{array}{c}20 \\
\left(\text { t.fed }^{-1}\right)\end{array}\right.$ & $\begin{array}{c}40 \\
\left(\text { t.fed }^{-1}\right)\end{array}$ & $\begin{array}{c}80 \\
\left(\text { t.fed }^{-1}\right)\end{array}$ \\
\hline $18-11-15$ & 22.40 & 0.84 & 0.76 & 0.46 & 0.40 & 0.37 & 0.40 & 0.30 & 0.16 & 0.74 & 0.60 & 0.52 \\
\hline $09-12-15$ & 26.80 & 0.94 & 0.86 & 0.54 & 0.42 & 0.33 & 0.48 & 0.34 & 0.26 & 0.85 & 0.71 & 0.66 \\
\hline $20-12-15$ & 28.40 & 1.20 & 0.94 & 0.58 & 0.46 & 0.39 & 0.51 & 0.47 & 0.36 & 0.91 & 0.84 & 0.74 \\
\hline $17-01-16$ & 36.90 & 1.60 & 1.22 & 0.76 & 0.62 & 0.54 & 0.66 & 0.36 & 0.43 & 1.20 & 0.99 & 0.90 \\
\hline $16-02-16$ & 20.20 & 0.92 & 0.72 & 0.42 & 0.34 & 0.28 & 0.36 & 0.28 & 0.16 & 0.65 & 0.51 & 0.47 \\
\hline $18-03-16$ & 27.50 & 1.40 & 0.92 & 0.66 & 0.52 & 0.45 & 0.56 & 0.44 & 0.38 & 0.94 & 0.80 & 0.72 \\
\hline Total & 162.20 & 6.90 & 5.42 & 3.42 & 2.76 & 2.36 & 2.97 & 2.19 & 1.75 & 5.29 & 4.45 & 4.01 \\
\hline
\end{tabular}


With regard to coal ash as soil conditioner under all storms, it is clear that runoff values reduced by $2.4,17.9$ and $26.0 \%$, respectively, by adding it by

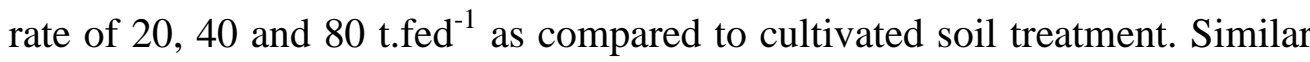
findings were obtained by Edwards et al. (1994); they stated that soil erodibility means the susceptibility of soil to erosive forces of raindrops impact and overland flow. Because soil erodibility is closely related to dynamic soil properties, so they suggest that soil erodibility exhibits temporal variations during storm event and can reduce it with adding soil conditioners.

Soil loss: The most important hazards results from water erosion is the removed of soil from eroding surface. It is known that detachment and transport process of water erosion occur by raindrops and runoff. In this part, the amount of soil loss affected by cultivation and some soil conditioners has been discussed as fallows:

The influence of the applied traditional cultivation and applied some soil conditioners on the amount of soil loss under natural rainfall is given in Table (4). The highest rates of soil losses resulted from bare soil treatment 1.23 ton/fed. Year this rate lies within the permissible limits of soil loss by erosion, which range from 1 to 5 tams per acre per years, Hudson (1981) and Morgan (2005). With respect to planting without soil conditioners, it is clear that such method reduced the amount of soil loss by $24.2 \%$ relative to that for bare soil treatment, Table (4). This behavior could be attributed to the fact that plants protect a portion of the soil surface from the energy of rainfall impact, thereby, soil detachment decreased. Growing plants also create obstructions to eater flow over land, slowing down runoff velocity and consequently its 
carrying capacity and thus, reducing soil loss. Similar results were obtained by Gumbs and Lindsay (1982).

Table (4) also reveals that applied coal ash soil conditioner on soil surface with the rate of 20,40 and 80 ton/fed reduced soil loss by 17.928 .9 and $36.9 \%$ as compared with that for cultivated soil treatment, receptivity. The bokashi conditioner applied with the rates of 20, 40 and 80 ton/fed reduced soil loss by 55.8, 66.9 and $77.6 \%$ relative to cultivated soil treatment. Table (4) also revealed that applying Ceramic conditioner with the rate of 20 , 40 and 80 ton/fed led to reduce soil loss by $48.3,56.3$ and $59.1 \%$ as compared with that for cultivated soil treatment. In this respect, Meyer et al. (1970) and Morgan (2005) mentioned that the application of 20 and 40 metric ton/ha as soil conditioner decreased soil loss to one - third of that from in traditional treatment. The data presented in Table (4) reveal that the relative effectiveness of soil conditioners on reducing the rate of soil erosion under the conditions of wadi El-Raml soil could be arranged in the flowing descending order bare soil - traditional cultivation without soil conditioners cultivation with Coal ash conditioner at rate of $20 \mathrm{t} . \mathrm{fed}^{-1}>$ cultivation with Coal ash conditioner at rate of $40 \mathrm{t} \cdot \mathrm{fed}^{-1}$ - cultivation with Coal ash conditioner at rate of $80 \mathrm{t} . \mathrm{fed}^{-1}$ - cultivation with Ceramic conditioner at rate of $20 \mathrm{t} . \mathrm{fed}^{-1}$ - cultivation with Bokashi conditioner at rate of $20 \mathrm{t} . \mathrm{fed}^{-1}$ - cultivation with Ceramic conditioner at rate of $40 \mathrm{t}_{\mathrm{fed}} \mathrm{d}^{-1}$ - cultivation with Ceramic conditioner at rate of $80 \mathrm{t} . \mathrm{fed}^{-1}$ - cultivation with Bokashi conditioner at rate of 40t.fed ${ }^{-1}$ - cultivation with Bokashi conditioner at rate of $80 \mathrm{t}_{\mathrm{fed}} \mathrm{ed}^{-1}$, respectively. From another point, the annual rate of surface water runoff or soil loss from the studied treatments followed the order: bokashi conditioner - 
Ceramic conditioner - Coal ash conditioner - cultivation without conditioners - bare soil. Therefore, the role of soil conditioner in controlling water erosion hazards under environment of North Western Coast Zone of Egypt at any rate followed the order: bokashi conditioner - Ceramic conditioner - Coal ash conditioner, approximately.

Table (4): Effect of Non- traditional soil conditioners on soil loss rate $\left({\mathrm{kg} . f e d^{-1}}^{-1}\right)$ under during winter season 2015/2016 at Wadi El-Ra

\begin{tabular}{|c|c|c|c|c|c|c|c|c|c|c|c|c|}
\hline \multirow{3}{*}{ Date storm } & \multirow{3}{*}{$\begin{array}{c}\text { Rainfall } \\
(\mathrm{mm})\end{array}$} & \multirow{3}{*}{$\begin{array}{r}\text { Bare } \\
\text { soil }\end{array}$} & \multirow{3}{*}{$\begin{array}{l}\text { Traditional } \\
\text { Cultivation }\end{array}$} & \multicolumn{3}{|c|}{$\begin{array}{l}\text { Cultivation with } \\
\text { Ceramic conditioner }\end{array}$} & \multicolumn{3}{|c|}{$\begin{array}{c}\text { Cultivation with } \\
\text { Bokashi conditioner }\end{array}$} & \multicolumn{3}{|c|}{$\begin{array}{l}\text { Cultivation with Coal } \\
\text { ashconditioner }\end{array}$} \\
\hline & & & & 20 & 40 & 80 & 20 & 40 & 80 & 20 & 40 & 80 \\
\hline & & & & (t.fed $\left.{ }^{-1}\right)$ & $\left(\right.$ t.fed $\left.^{-1}\right)$ & $\left(\right.$ t.fed $\left.^{-1}\right)$ & (t.fed ${ }^{2}$ & $\left(\right.$ t.fed $\left.^{-1}\right)$ & $\left(\right.$ t.fed $\left.^{-1}\right)$ & $\left(\right.$ t.fed $\left.^{-1}\right)$ & $\left(\mathrm{t}_{\mathrm{fed}}{ }^{-1}\right)$ & $\left(\mathrm{t}^{-\mathrm{fed}^{-1}}\right)$ \\
\hline 18-11-15 & 22.40 & 160 & 125 & 52.2 & 55 & 51.3 & 52.5 & 41.2 & 28.6 & 92.4 & 84.4 & 72.6 \\
\hline $09-12-15$ & 26.80 & 180 & 132 & 62.4 & 58.1 & 54.1 & 56.4 & 44.4 & 30.8 & 99.6 & 87.2 & 73.9 \\
\hline $20-12-15$ & 28.40 & 220 & 145 & 68.7 & 62.4 & 59 & 62.1 & 47.5 & 31.7 & 109.5 & 98.6 & 82.8 \\
\hline $17-01-16$ & 36.90 & 330 & 280 & 142.4 & 124.9 & 116.4 & 128.8 & 93.7 & 62.5 & 266.9 & 218.2 & 204.3 \\
\hline $16-02-16$ & 20.20 & 140 & 105 & 51.7 & 42.8 & 34.9 & 47.2 & 33.7 & 22.4 & 82.3 & 71.4 & 58.2 \\
\hline $18-03-16$ & 27.50 & 200 & 145 & 72.8 & 64.2 & 56.8 & 64.9 & 48.2 & 32.1 & 114.2 & 102.9 & 96.5 \\
\hline Total & 162.20 & 1230 & 932 & 450.2 & 407.4 & 372.5 & 411.9 & 308.7 & 208.1 & 764.9 & 662.7 & 588.3 \\
\hline
\end{tabular}

Therefore, it can be concluded that using non- traditional conditioners, such as bokashi, ceramic or coal ash, with cultivation under environment of North Western Coast Zone of Egypt will combat the hazards of water erosion. The bokashi conditioner at rate of $80 \mathrm{t}_{\mathrm{fed}} \mathrm{f}^{-1}$ is considered the best conditioner for controlling water erosion hazards, where the annual reduction in surface water runoff and soil loss reached 75 and $88 \%$, respectively, as compared to that for bare soil. 


\section{REFFERENCES}

Abdel- Kader, F. (1998). GIS analysis of landscape units for coastal area management of Fuka basin. Alex. J. Agri. Res., 43:109 - 127.

Abou Youssef, M. F., M. M. Kotb and A. A. Ali (2005). Assessment of actual soil erosion risk using CORINE model in North Western Coast of Egypt. Egypt. J. Appl. Sci., 20 (5A): 412-428.

Ali, A. A. (1998). Water Erosion and Properties of the Eroded Materials under Different Management System. Ph. D. Thesis, Faculty of Agriculture, Suez Canal University, Ismailia, Egypt.

Ali. A. A. (2006). Rainfall erosivity and soil erodibility as indicator for water erosion rate in some areas of Egypt. J. Environmental Research, 7: $1-10$.

Bay Ram, N. I.; O. Dengz; O. Baskan and M. Darlak (2003). Soil erosion risk assessment with ICONA model; Case study: Bey Pazan area. Turk. J. Agric. and Forestry. 27: 105-116.

Climatological Normals for the Arab Republic of Egypt. (1979). Ministry of Civilization, Meteorological Authority, Cairo, Egypt.

Debeny, S. M., C. E. Murphree and L. D. Meyer (1993). Tillage, row spacing and cultivation affect erosion from soybean cropland. Trans. Of the ASAE, 46 (1): 87-94.

Delbaera, B. (2003). Environmental Risk Assessment for European Agriculture. Interim Report - Tilburg European Centre for Nature Conservation.

Edwards, W. M.; G. B. Triplett; D. M. Van Doren, L. B. Owens; C. E. Redmend and W. A. Dick (1993). Tillage studies with a corn soybean relation: Hydrology and Sediment loss. Soil Sci. Soc. Am. J. 57: 1051- 1055.

FAO (1993). Field Measurement of Soil Erosion and Runoff, Soil Bull. No. 68. N. W. Hudson, Rome.

FAO (2006). Agro. Maps: A Global Spatial Data Base of Sub-National Agricultural Land Use Statistics. In Land and Water Digital Media Series, Vol. 32. FAO, Rome. 
Gachene, C. K. K.; N. J. Jarvis; H. Linner and J. P. Mbuvi (1997). Soil erosion effects on soil properties in a high land area of central Kenya. Soil Sci. Soc. Am. J. 61: 559-564.

Hudson, N. W. (1981). Soil Conservation. Cornell Univ. Press. Ithaca, New York, $2^{\text {nd }}$ Ed.

Kaltenrieder, J. (2007). Adaptation and Validation of the Universal Soil Loss Equation (USLE) for the Ethiopian - Eritrean High Land. M.Sc. Thesis, University of Berne, Centre for Development and Environment Geographisches Institute.

Kamel, A. (2011). Cultural practices to combat degradation under rainfed areas in the Northern Coastal Plain in Egypt. International J. of Water Resources and Arid Environments. (5): 304 - 311.

Klute, A. (1986). Methods of Soil Analysis. Part (1): Physical and Mineralogical Methods. No.9 in the Agronomy Series. Amer. Soc. of Agron. and Soil Sci. Soc. of America (Publisher). Second Edition. Madison, Wisconsin, USA.

Liu, B. Y.; M. A. Nearing and L. M. Risse (1994). Slope gradient effect on soil for steep slopes. Trans. of the ASAE, 37 (6): 1835 - 1840.

Lul Seged, T. and G. L. P. Viek (2008). Soil Erosion Studies in Northern Ethiopia. Springer Science Business Media B.V.

Morgan, R. P. C. (1995). Soil Erosion and Conservation. Silsoe College, Cranfield University. Second Edition.

Page, A. J.; R. H. Miller and D. R. Keeney (1982). Methods of Soil Analysis. Part 2. No. 9. In the Agronomy Series. Amer. Soc. of Agron. Madison, Wisconsin, UAS.

Renschler, C.; C. Mannaerts and B. Dickkrager (1999). Evaluating spatial and temporal variability in soil erosion risk- rainfall erosivity and soil loss rates in Ando Lusia, Spain. CAT ENA, 34: 209-225.

Rousseva, S.; L. Iozanova; D. Nekova; V. Stefanova; Ch. Djodjov; E. Tsvetkova; I. Malinov; V. Kroumov and S. ChehlarovaSimeonova (2010). Soil Erosion Risk in Bulgaria and 
Recommendations for Soil Protective Use of Agricultural Land. Port 1. North Bulgaria. Publish SciSet- Eco, Sofia, 304P.

Santra, P.; R. S. Mertia and H. L. Kushawa (2010). A new wind erosionsampler for monitoring dust-storm events in the Indian Thar desert. Current Science, 99 (8):1061-1067.

Shata, A. A. (1991). Water resources and the future of arid lands. Roundtable meeting, RIGW/IWACO, Cairo- Rotterdam.

Shiferaw, A. (2011). Estimating soil loss rates for conservation planning in the Bore Nawored of south Wollo High Lands, Ethiopia. Journal of Sustainable Development in Africa. 3-13.

Truman, C. C. and J. M. Bradford (1995). Laboratory determination of interrill soil erodibility. Soil Sci. Am. J. 59: 519-526.

United Nation (1992). The Environment in Europe and North America, Annotated Statistics 1992, United Nations Publ., New York. USA.

Vertiman, W. (1989). Report on Qasr Rural Development Project. Matrouh Governorate, Egypt. 


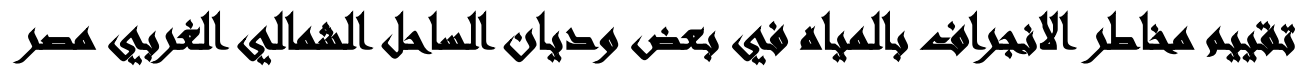

[V]

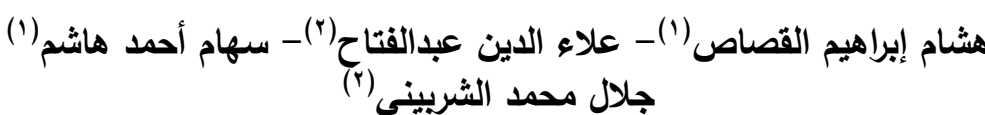 \\ ( ) معهد الدراسات والبحوث البيئية، جامعة عين شمس r ج) مركز بحوث الصحراء

\section{المستخلص}

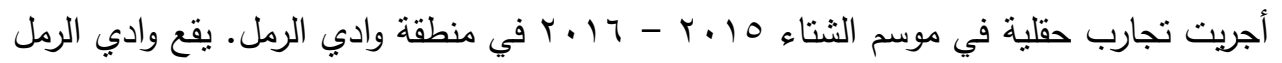

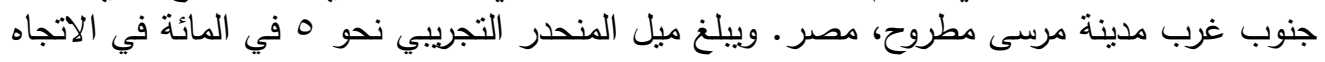

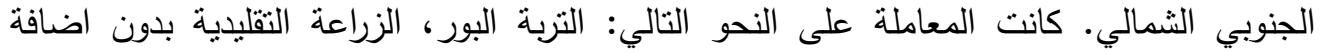

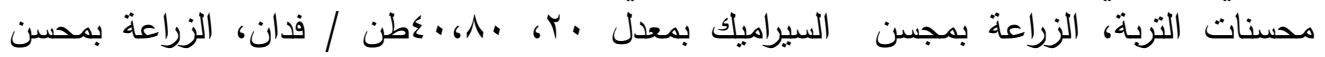

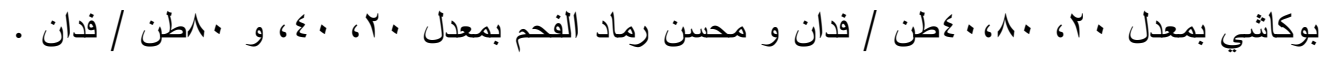

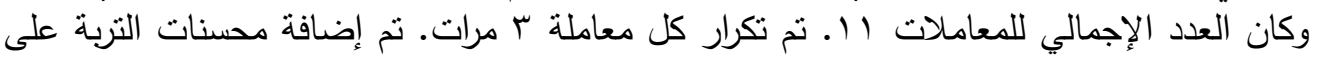

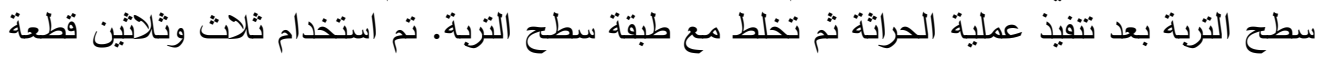

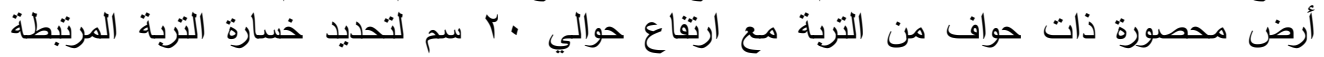

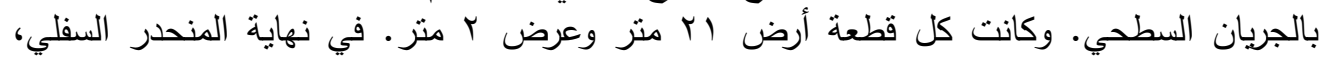

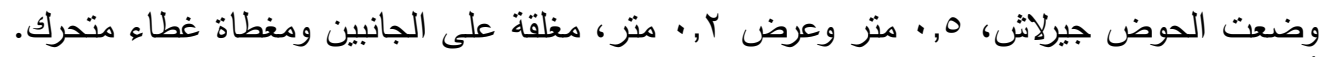

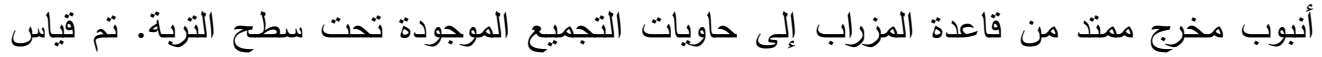

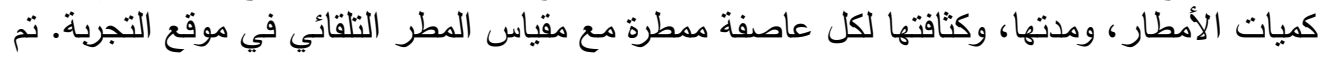

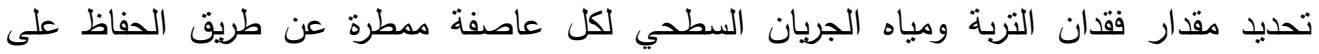
الحاويات دون عائق لفترة كافية، بحيث تترسب التبان المكونات الصلبة في مياه الجريان. نم جمع المواد

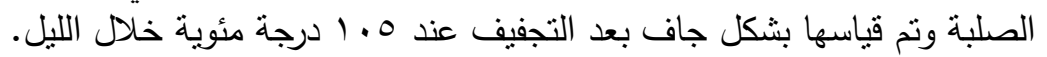

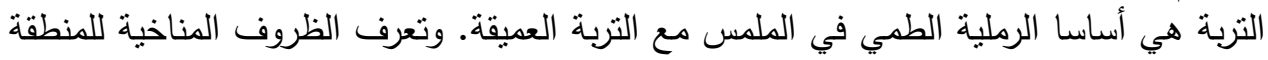

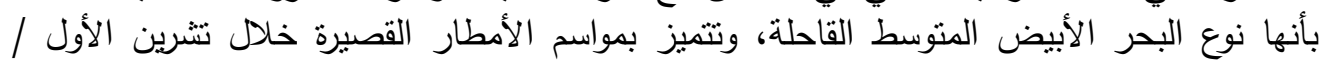

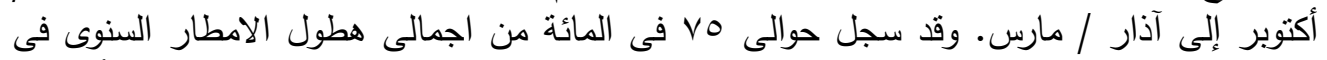

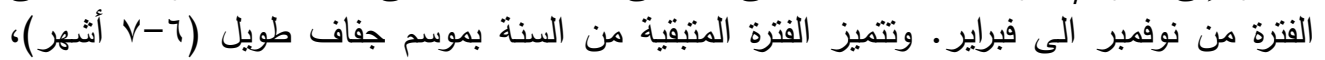

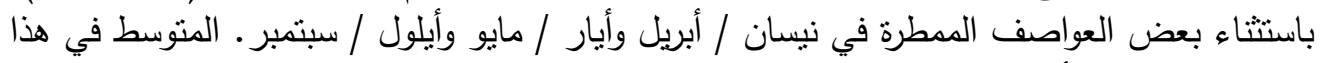

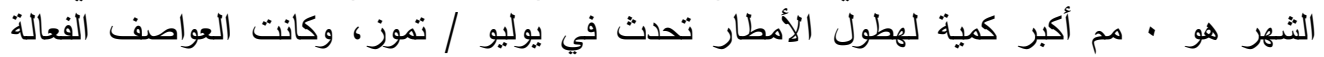

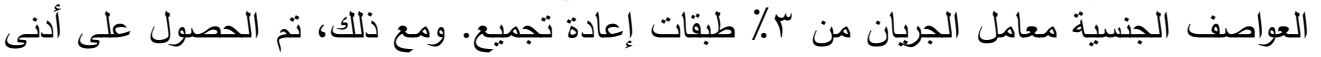

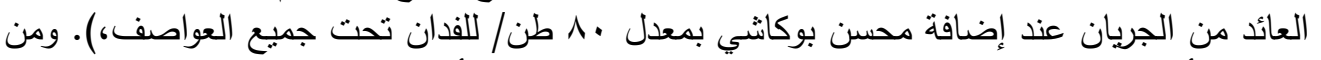

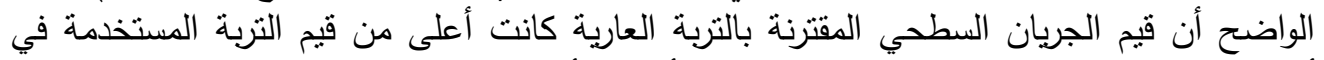
أجهزة محسنات التربة غير التقليدية. ومن جهة أخرى، أدى محسن السيراميك المضافة التهان على سطح 162 


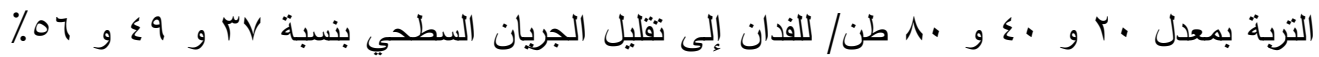

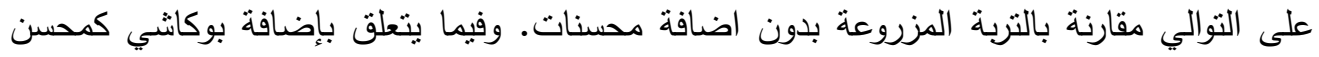

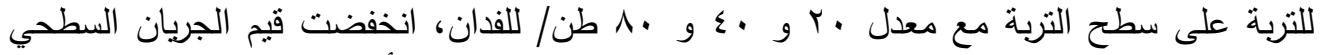

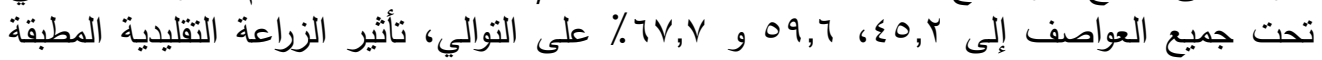

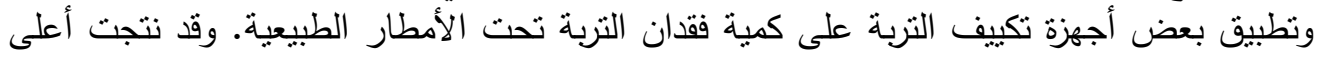

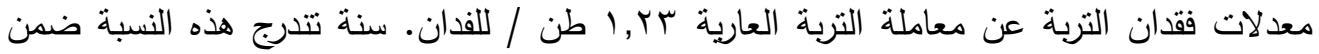

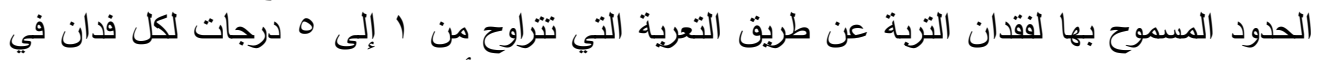

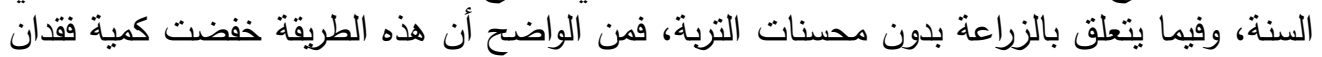

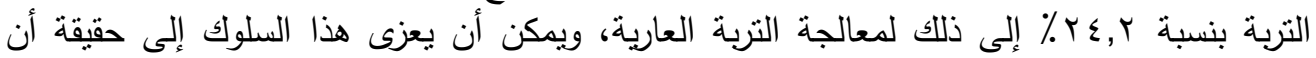

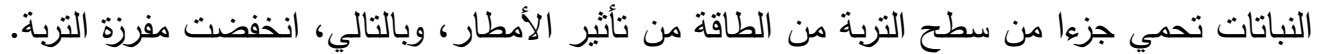

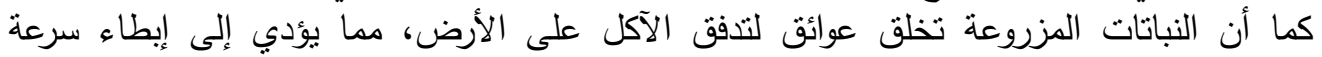

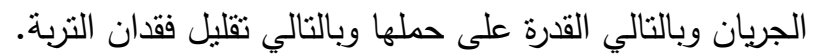
الكلمات المفتاحية: انجراف التربة بالماء - مخاطر الإنجراف - الجريان السطحي - فاقد التربة -

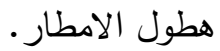

